\title{
Regional Entrepreneurship Capital and Firm Production
}

Post-print of: Massón-Guerra, José Luís ; Ortín-Ángel, Pedro. "Regional entrepreneurship capital and firm production" in Small Business Economics (Springer) First Online: 5 april (2017) ISSN 0921-898X.

The final publication is available at Springer via http://dx.doi.org/10.1007/s11187-017-9851-0

\section{José Luis Massón-Guerra - Pedro Ortín-Ángel}

\begin{abstract}
Certain theories suggest that the capacity of a region to generate new firms, called entrepreneurship capital, has positive spillover effects on the production of the firms in that region. Evidence generated with aggregated data at the regional level supports this prediction. This paper argues that, using aggregated data at the regional level, entrepreneurship capital could be correlated with regional production even if entrepreneurship capital has no spillover effects on firm production. This will not be the case when data at the firm level are used. This paper provides evidence from a sample of 11,276 Spanish firms during the 2004-2012 period. Positive spillovers are estimated in between effects models, but such spillovers are only found in technological firms when within effects models have been estimated. Thus, the regional entrepreneurship capital spillovers are unclear when data at the firm level are used. Plausible interpretations and implications are discussed.
\end{abstract}




\section{Introduction}

The Knowledge Spillover Theory of Entrepreneurship (KSTE) suggests that entrepreneurship capital in a certain region has positive spillovers that increase the production of firms in the region (Audretsch and Keilbach 2005, 2007; Acs et al. 2009; Audretsch and Lehmann 2016). From this starting point, a growing amount of literature is estimating the effects of regional entrepreneurship capital on a region's production using aggregated data at the regional level (Audretsch and Keilbach 2004a,b,c, 2005, 2008; Mueller 2006, 2007; Bönte et al. 2008; Cravo et al. 2010; Stough et al. 2008; Chang et al. 2012; Hafer 2013; Laborda et al. 2011; Carree et al. 2014; Mendonça and Grimpe 2015). In practically all the cases, these studies report the positive and significant effects of regional entrepreneurship capital on regional production, which are interpreted as supporting the existence of positive spillovers.

The measurement and concept of entrepreneurship capital has been discussed, unlike the measurements of other kinds of inputs (Erikson 2002; Audretsch and Keilbach 2004a; Bönte et al. 2008). The empirical applications work with different measures that range from the stock of new firms in the region (Audretsch and Keilbach 2004a,b,c, 2005, 2008) to the entry rate of firms in key industries (Chang et al. 2012). Most of the entrepreneurship capital measures used ${ }^{1}$ are part of (and can therefore be related to) the number of firms in the region (Henrekson and Sanandaji 2014).

This paper argues that the regional entrepreneurship capital could affect the regional aggregated production by at least two means: by affecting the number of firms in the region and/or by affecting the spillovers in firm production. The next section of this paper discusses why using data aggregated at the regional level makes it very difficult to distinguish between these two effects. Therefore, data need to be gathered at the firm level to properly test whether entrepreneurship capital has positive spillovers on a regional level that increase the production of firms in this region, as suggested by the Knowledge Spillover Theory of Entrepreneurship and other theoretical arguments such as the increase of competition suggested by Geroski (1989) or Roberts and Tybout (1996).

\footnotetext{
${ }^{1}$ Other authors have used the annual average of new firms per 1,000 workers created in a three-year period, such as Audretsch and Keilbach (2004a,b, 2008). Mueller (2006, 2007) uses this indicator in addition to the number of new firms created in one year. Sutter and Stough (2009) use the average number of technological and innovative firms created in the last five years, while Bönte et al. (2008), Salas-Fumás and Sánchez-Asín (2013a,b) and Stough et al. (2008) use the self-employment rate on a regional level. Erken et. al (2016) use the business ownership rate (number of business owners per workforce) corrected for the level of economic development (GDP per capita) to evaluate the relation between entrepreneurship and total factor productivity.
} 
Acs et al. (2016) argues "that spatial externalities of various forms constitute serious market failures that require intervention" (p. 36). Thus, it is important to properly measure the existence and amount of such externalities to justify government intervention and the quantity of resources devoted to such an intervention. Therefore, we have collected information about the entrepreneurship capital in Spanish Autonomous Communities (NUTS 2 in accordance with Eurostat) from INE ${ }^{2}$. From the Spanish Technological Innovation Panel ${ }^{3}$, we construct an unbalanced data panel of 11,276 Spanish firms during the 2004-12 period with information about the production obtained, the capital and the labour used by each firm. As far as we know, this paper is the first to have used data at the firm level to provide evidence for the effect of spillovers of regional entrepreneurship capital on existent firms' production. In addition to a more proper measure of the regional entrepreneurship capital spillovers, data at the firm level have many other advantages over data aggregated at the regional level. For example, the data allowed us to work with an exponentially higher number of observations and to analyse which kind of firms benefits the most from regional entrepreneurship capital.

The paper is organized as follows. In Section 2, the previous literature methods are summarized and their limitations discussed. Section 3 discusses the methodological approach used in this paper and states the hypotheses. In Section 4, we present the data. Section 5 presents the estimations of firms' production functions. Section 6 concludes the paper by discussing its implications.

\section{A main shortcoming of the previous literature}

Most of the literature cited in the introduction has estimated the impact of regional entrepreneurship capital on the production for region $i$ at period $t, Y_{i, t}$. The usual method is to act in accordance with that used by Solow (1956). The regional output is obtained as a combination of the sum of inputs purchased by the firms of the region and other regional inputs. Cobb-Douglas (1928) functions are usually estimated, and the inputs considered are labour $\left(L_{i, t}\right)$, (physical) capital $\left(K_{i, t}\right)$, regional knowledge $\left(R_{i, t}\right)$ and regional entrepreneurship capital $\left(E_{i, t}\right)$ :

$\ln Y_{i, t}=\beta \ln L_{i, t}+\alpha \ln K_{i, t}+\mu \ln R_{i, t}+\delta \ln E_{i, t}+\varepsilon_{i, t}$,

\footnotetext{
${ }^{2}$ http://www.ine.es/

${ }^{3}$ http://icono.fecyt.es/PITEC/Paginas/por_que.aspx
} 
where $\varepsilon_{i, t}$ captures the usual error terms. According to the study, the error terms may include time and/or regional fixed effects. Usually, except for specific cases (see Carre et al. 2014), regional cross effects are not considered. Hence, the main parameters estimated are production elasticity with respect to labour $(\beta)$, capital $(\alpha)$, regional knowledge $(\mu)$ and regional entrepreneurship capital $(\delta)$. The estimations of the elasticity of production with respect to regional knowledge and regional entrepreneurship capital are usually positive and statistically significant.

The literature has interpreted the positive relationship between regional entrepreneurship capital and regional production as evidence of the regional entrepreneurship capital spillovers on firms' production. This interpretation is not free of assumptions. To make such assumptions explicit, we will formalize our arguments. This formalization is based on the previous analyses of the limitations related to the use of regional aggregated production functions (see Fisher 1969, 2005 for further details).

In each period, a set of inhabitants of the region decide to be (or continue to be) entrepreneurs, thus determining the number of firms in the region, $n_{i, t}$. These firms will contract for a set of inputs to produce outputs in accordance with the production function described by the following equation:

$Y_{j, i, t}=L_{j, i, t}^{(1-\gamma-\mathrm{s})}\left(K_{j, i, t} / L_{j, i, t}\right)^{\alpha} R_{i, t}^{\mu} E_{i, t}^{\delta} S_{i, t}^{s}$,

where $L_{j, i, t}$ is the size of each firm measured in terms of employment, the stock of capital per employee is $k_{i, t}=K_{j, i, t} / L_{j, i, t}, S_{i, t}$ is the average size of the firms in the region, and $\gamma, \alpha, \mu, \delta$ and $s$ are parameters. By definition, the outputs and certain inputs at the regional level are the aggregate of those used by the $n_{i, t}$ firms $\left(j=1, \ldots, n_{i, t}\right)$ in region $i$ in period $t: Y_{i, t}=\sum_{j=1}^{n_{i, t}} Y_{j, i, t}$, $K_{i, t}=\sum_{j=1}^{n_{i, t}} K_{j, i, t}$, and $L_{i, t}=\sum_{j=1}^{n_{i, t}} L_{j, i, t}$. If all the firms in the region have the same size $\left(S_{i, t}=\right.$ $L_{j, i, t}$ ), it is easy to show that the regional production is

$Y_{i, t}=n_{i, t} Y_{i, j, t}=n_{i, t}^{\gamma+s} L_{i, t}^{(1-\gamma-s)} k_{i, t}^{\alpha} S_{i, t}^{s} R_{i, t}^{\mu} E_{i, t}^{\delta}=n_{i, t}^{\gamma} L_{i, t}^{1-\gamma} k_{i, t}^{\alpha} R_{i, t}^{\mu} E_{i, t}^{\delta}$,

where $\gamma=1-\alpha-\beta$ measures the returns to scale at the regional aggregated level, while the returns to scale at the firm level are $\gamma+s$. Those returns differ when the average size of the firms in the region has spillovers on the production of the firms in this region, $s \neq 0$. 
It is easy to verify that in those particular cases, when the regional aggregated level returns to scale are constant $(\gamma=1-\alpha-\beta=0)$ or $s=-\gamma$, the regional production is $Y_{i, t}=n_{i, t} Y_{i, j, t}$ $=L_{i, t} k_{i, t}^{\alpha} R_{i, t}^{\mu} E_{i, t}^{\delta}=L_{i, t}^{\beta} K_{i, t}^{\alpha} R_{i, t}^{\mu} E_{i, t}^{\delta}$. Taking logarithms and adding error terms, this equation is equal to Equation 1, which is the one used in the literature. In short, these are the main assumptions (implicitly) made by the previous literature.

In practically all of the studies revised (with the exception of Audretsch and Keilbach 2004b), the parameters estimated by Equation [1] show decreasing returns to scale $(\gamma=1-\alpha-\beta>0)$, although only Mueller (2006) reports a test of their significance. Thus, it is difficult to accept the assumption that, at the regional aggregated level, returns to scale are constant.

Therefore, the alternative is to assume that the average size of the firms $S_{i, t}$ is a regional input with an elasticity equal to $s=-\gamma=-(1-\alpha-\beta)$. The problem with aggregated data at the regional level is that we cannot provide evidence about the value of $s$. When $\gamma+s>0$, the previous literature has omitted a relevant variable, the number of firms in the region. This finding is important, because it appears reasonable to expect that the measures of entrepreneurship capital used $\left(E_{i, t}\right)$ are positively correlated with the number of firms in the region, $n_{i, t}$. As previously discussed in the introduction, most of the measures of entrepreneurship capital used previously in the literature are based on the number of firms. Thus, it is expected that the number of firms is positively related to the entrepreneurship capital in the region. In this case, the literature is overestimating the real spillovers of entrepreneurship capital on firms' production.

For illustrative purposes, let us assume that the correlation between entrepreneurship capital and the number of firms is one, and specifically that $E_{i, t}=n_{i, t}$. Let us call $\hat{\delta}$ the estimated coefficient of the entrepreneurship capital using Equation [1]. In accordance with Equation [3], $\delta=\delta+\gamma+$ $s$; therefore, the bias will depend on the presence of returns to scale $\gamma$ and on the spillovers of the regional average size of the firms on the production of the firms in the region, s. In fact, we cannot exclude the possibility that the entrepreneurship capital does not affect the production at the firm level $(\delta=0)$, although there is evidence showing a positive effect on the production aggregated at the regional level $(\hat{\delta}>0$ since $\gamma+s>0)$. This finding is an important shortcoming of the previous literature, since it casts doubt on their main interpretation of the evidence generated, that the regional entrepreneurship capital has positive spillovers on the production of the firms in the region. This bias disappears using data at the firm level to estimate Equation [2]. 
Data at the firm level also enables us to address new issues other than those in the cited literature. Some of the papers revised seek to identify the kind of entrepreneurship capital that generates more spillovers. For example, Audretsch and Keilbach (2004a,b,c, 2008) classified entrepreneurship capital on the basis of the technological intensity of the sectors: high technology, ICTs, and other sectors. The researchers find that other sectors that are less technological generate more spillovers. In terms of geographical location, urban zones generate higher spillovers than rural ones (Audretsch and Keilbach 2005). Data at the firm level allows us to extend those analyses and estimate the elasticities of production with respect to entrepreneurship capital for different groups of firms. Consequently, we can identify the groups of firms that benefit the most from entrepreneurship capital spillovers (i.e., which receive more externalities). The KSTE justifies those spillovers by the role of entrepreneurship capital in the diffusion of knowledge. The evidence can therefore be interpreted in terms of the differences in the absorptive capacity of knowledge between firms.

\section{The methodological approach}

We use the number of firms per inhabitant in the region as the measure of regional entrepreneurship capital ${ }^{4}, E_{i, t}=\frac{n_{i, t}}{P_{i, t}}$. Implicitly, we assume that the number of firms in the region $\left(n_{i, t}\right)$ is determined by the population of the region $\left(P_{i, t}\right)$ and the entrepreneurship capital in the region $\left(E_{i, t}\right)$. The focus of our analyses, and that of the previous literature, is not to quantify the effects of entrepreneurship capital on regional GDP via the increases in the number of firms, $\left(Y_{i, t}=\sum_{j=1}^{n_{i, t}} Y_{j, i, t}\right)$; instead, it is to measure the spillovers of regional entrepreneurship capital on firms' production. In other words, the focus is to test whether $Y_{j, i, t}$ depends on $E_{i, t}$. The previous section has noted the problems in disentangling both effects using data aggregated at the regional level. Thus, we use data at the firm level to estimate the firms' production function (Equation [2] in logarithmic terms), which is defined in the section above:

$\ln Y_{j, i, t}=\beta \ln L_{j, i, t}+\alpha \ln K_{j, i, t}+\mu \ln R_{i, t}+\delta \ln E_{i, t}+s \ln S_{i, t}+\varepsilon_{j, i, t}$.

Given the purpose of this paper, in accordance with the previous literature measuring only the entrepreneurship capital spillovers in the firms of the same region, we do not consider cross-

\footnotetext{
${ }^{4}$ Normalizing $P_{i, 0}=1$ and assuming that the population of the region remains constant along time, and $P_{i, t}=$ 1 , we obtain the case analysed in the previous section in which the entrepreneurship capital in the region is equal to the number of firms, $E_{i, t}=n_{i, t}$.
} 
border effects. Apart from the inclusion of entrepreneurship capital (and the average size of the firms in the region), these kinds of equations have been extensively estimated in other contexts (see Syverson 2011 for further discussion of their limitations). The following discussion is focused on the proposed measure of entrepreneurship capital: $E_{i, t}=\frac{n_{i, t}}{P_{i, t}}$.

Obviously, we will not argue that everyone in the population has the same probability of being an entrepreneur nor that all types of entrepreneurs provoke the same spillovers. For example, the persistence of the decision of being an entrepreneur is well documented (for a recent discussion, see Fritsch and Wyrwich 2014). Consequently, the probability of being an entrepreneur is higher for those who were entrepreneurs the previous year (persistent entrepreneurs) than for the remainder of the population (entrant entrepreneurs). Certain authors claim (Congregado et al. 2012) that, among the persistent entrepreneurs, there will be a relatively higher presence of entrepreneurs who play the risk-bearing arbitrageur role, emphasized by the writings of Knight (1921), Say (1803) and Kirzner (1979), than the role of innovative entrepreneurs, highlighted by Schumpeter (1950).

In accordance with the KSTE, innovative entrepreneurs will cause relatively more spillovers and appear to be more present among the entrant entrepreneurs. Therefore, Audretsch and Keilbach (2004a,b, 2008) use the annual average of new firms per 1,000 inhabitants created in a three-year period as the measure of entrepreneurship capital. This ratio can be related with the probability of an inhabitant of the region creating a new firm. Unfortunately, we do not have data regarding the regional startups for each year; therefore, we cannot provide empirical evidence analysing the differences among both measures. Previous evidence suggests that those measures are highly correlated (Fritsch and Wyrwich 2014). This finding is consistent with recent theoretical approaches (Van den Steen 2010; Gutiérrez and Ortín-Ángel 2016) arguing that, in any case, an important role of entrepreneurs is to establish a use of productive factors that otherwise would not exist.

Nevertheless, we can test whether the entrepreneurship capital in a region affects the production $(\delta>0)$ of those firms located in the region.

Hypothesis 1: The production of firms in a region is positively related to regional entrepreneurship capital. 
As previously noted, certain authors use the average of the entrepreneurship capital during certain time periods because, as is argued, the entrepreneurship capital is a latent variable. To focus our argument, let us assume that the measure used is related to the entrepreneurship capital in the following manner: $m_{i, t}=\frac{n_{i, t}}{P_{i, t}}=E_{i, 0} \prod_{1}^{t} e^{\theta \Delta_{i, t}+(1-\theta) v_{i, t}}$. The error measurements are captured by $v_{i, t}$, where $t$ is independent random variables with a mean equal to zero. The relative importance of the measurement errors with respect to the annual variation in entrepreneurship capital $\Delta_{i, t}$ is measured by the parameter $\theta \in[0,1]$. When $\theta=1, m_{i, t}$ is the most accurate measure of the entrepreneurship capital, and when $\theta=0$, the most accurate measure is the average (of logarithms) of $m_{i, t}$ during the period analysed. Other approaches use time series techniques. For an example ${ }^{5}$, refer to Congregado et al. (2012).

Our approach utilizes the fact that we have an unbalanced data panel referring to 11,276 firms ( $j$ ) distributed throughout 18 regions $(i)$ with an average of 7.9 observed years per firm $(t)$; thus, there are ultimately 89,370 observations. We can estimate the elasticity of production with respect to the measure of entrepreneurship using the fixed effects (or within) model $\left(\delta^{w}\right)$. Furthermore, disaggregated data at the firm level enable us to estimate the between effects model (and the correspondent elasticity $\delta^{b}$ ) with 11,276 observations instead of the 18 observations that would be used for data aggregated at the regional level.

Assuming that entrepreneurship capital is related to the production of the firms in accordance with Equation [2], and the annual variation in entrepreneurship capital $\Delta_{i, t}$ is cyclical ( $\sum_{t=1}^{T} \ln m_{i, t} / T=\ln E_{i, 0}$, where $T$ is the number of periods observed), we expect that $\delta^{w}=\delta^{b} \theta$. Therefore, the elasticities estimated will be the same when $\theta=1$ and differ otherwise (according to the estimations of Congregado et al. 2012, the value of this parameter for Spain is approximately 0.28 for the 1987 to 2008 period). In this last case $(\theta<1)$, we cannot exclude other sources of differences in those parameters, such as the omission of time invariant variables correlated with the entrepreneurship capital or that Equation [2] is not the underlying production function.

As discussed in the section above, data at the firm level also allow us to identify those firms that benefit more from entrepreneurship capital spillovers. In accordance with the KSTE, entrepreneurship is a facilitator of knowledge dissemination. Consequently, it is expected that

\footnotetext{
${ }^{5}$ According to Congregado et al. (2012) terminology, $E_{i, 0}$ is the non-stationary natural rate component, and $\Delta_{i, t}$ is the stationary cyclical component.
} 
entrepreneurship capital spillovers will be higher in those firms with lower current levels of knowledge and in firms with a higher capacity to learn, or absorptive capacities (Cohen and Levinthal 1990; Qian and Acs 2013). As a proxy of these two concepts, we use the size of the firm and its technological intensity. The technological intensity has been related to firms' higher absorptive capacities from the outset (Cohen and Levinthal 1990). Furthermore, we postulate that small firms have fewer resources; therefore, on average, we expect that they have accumulated lower levels of knowledge and thus have more to learn. In short, we propose the following hypothesis:

Hypothesis 2: The benefits from entrepreneurship capital spillovers decrease with the size of the firm and increase with its technological intensity.

As in much of the literature on firms' productivity (Syverson 2011 for a summary), Equation [1] and [2] are interpreted in terms of how the production is organized, without considering that there is a process of input accumulation that occurs nearly simultaneously. Audretsch and Keilbach (2004a,c, 2008) argue that estimations based only on Equation [1] could suffer from an endogeneity problem ${ }^{6}$, which arises when the measure of entrepreneurship capital is correlated with the production function error. Although this correlation is expected to be lower when using data at the firm level (Equation [4]), in accordance with Audretsch and Keilbach (2004a,c, 2008), we provide simultaneous estimations of the consequences of entrepreneurship capital on firms' production, Equation [4], and the determinants of the stock of entrepreneurship capital, Equation [5]:

$\ln E_{i, t}=\sum_{z} \pi_{z} \mathrm{Z}_{z, i, t-1}+v_{i, t}$

where $Z_{z}$ are the $z$ possible determinants of entrepreneurship capital, $\pi_{z}$ are the parameters to be estimated and $v_{i, t}$ are the usual error terms. The estimator of the relationship between firms' production and entrepreneurship capital that provides the simultaneous equation estimation is a full information instrumental variable (Hausman 1978) in that it considers the possible correlation between error terms and regressors and between the error terms of the two equations.

To consider the persistence of the regional levels of entrepreneurship, we will introduce the entrepreneurship capital of the last year as an independent variable in Equation [5]. Although the

\footnotetext{
${ }^{6}$ The next considerations regarding entrepreneurship capital can be extended to the remainder of inputs in Equation [2]. As the focus of the paper is based on the entrepreneurship capital, we omit such analyses.
} 
persistence is important, the decision of being an entrepreneur may evolve over time due to changes in their financial situation, economic perspectives, regional government policies and other personal situations.

Therefore, we have collected information concerning wealth, the aggregated value added and the population density, as well as the economic perspectives of the region and the annual increase in the aggregated value added. The existing evidence (see Koellinger and Thurik 2012 for a discussion) is ambiguous about the relationship between the previous general economic conditions of the inhabitants of a region and the current entrepreneurship capital of the region.

An analysis of each regional government policy is beyond our research purpose. One of the main instruments for such policies is tax. We have collected information about the tax pressure in each region. Consistent with the evidence available (for further discussion see Gentry and Hubbard 2004), we expect a positive relationship between the previous tax pressure and the current entrepreneurship capital.

Finally, one of the most dramatic changes in the personal situation is to become unemployed. We include information about the regional unemployment rates. Consistent with the existing evidence (for a more detailed discussion see Fairlie 2013), we expect that entrepreneurship capital will increase in those regions with previously higher unemployment rates.

\section{Data}

The firms' data used in this study originate from the Spanish Technological Innovation Panel (PITEC) and refer to the 2004-2012 period. This is an unbalanced data panel (each year some firms join and others leave the panel). We use the information corresponding to the firms' research activity and location of headquarters to allocate the firms to a specific Spanish region (further details about the allocation process are provided in Appendix 1). Those R\&D activities are expected to play a key role in the diffusion/absorption of knowledge. On average, we have 7.9 observations per firm and 11,276 firms; therefore, we use a total of 89,370 observations. Next, we define the variables collected at the firm level. All monetary variables are expressed in 2000 constant Euros. Table 1 presents the descriptive statistics of the variables.

Insert Table 1 about here 
Region (i): this variable indicates the Spanish Autonomous Community where the firm is located. Output $\left(Y_{j, i, t}\right)$ : measures the firm's annual production. This variable was defined by the sales volume of each firm in real terms. Labour $\left(L_{j, i, t}\right)$ is measured by the number of employees engaged in production activities. In Appendix 2, we explain the procedure to obtain the stock of capital $\left(K_{j, i, t}\right)$ of a firm. Private Knowledge $\left(Z_{j, i, t}\right)$ is measured by the investment in R\&D activities.

The firms can be classified in different categories in accordance with their technological intensity and size. Based on the methodologies developed by the Organization for Economic Cooperation and Development (OECD) and EUROSTAT, the Spanish National Statistics Institute (INE) classifies economic sectors in accordance with their technological intensity: very high tech service sectors (HT), high and medium tech manufacturing sectors (MT), and other sectors. The INE defines technology sectors as those characterized by rapid knowledge renewal and that require a continuous and concerted effort to foster research and technological foundation (see Table 2).

Insert Table 2 about here

In accordance with the EUROSTAT classification of enterprises, firms can be classified into three categories according to the number of employees: small (1-49 employees), medium (50-249 employees) and large firms. Table 3 shows the distribution of firms by technological intensity and size categories. Therefore, a maximum of nine categories can be used in the analyses. For simplicity purposes, in this paper, we present the analyses that best summarize the results. We use two dummies, one for size (50 or more employees) and another for technological intensity (includes HT and MT firms) ${ }^{7}$. The category omitted in the analyses is firms with less than 50 employees and of low technological intensity.

Insert Table 3 about here

For each region, in our case Autonomous Community $(i=1, \ldots, 18)$, we have collected the following aggregated information.

Regional Knowledge $\left(R_{i, t}\right)$ is measured by the number of patents filed each year based on the Spanish Patents and Trademarks Office (Bönte et al. 2008). Unfortunately, we do not have access to data to estimate other proxies used in previous studies, for example, the total number of people

\footnotetext{
${ }^{7}$ All the analyses that are cited but not provided in the text are available on request from the authors.
} 
employed in private companies or universities in areas related to R\&D (Mueller 2007) or the annual regional costs of R\&D (Griliches 1998).

The information on the stock of firms $\left(n_{i, t}\right)$ in each region is available in the Central Business Register (DIRCE) database. The entrepreneurship capital is measured by the ratio between the stock of firms and the regional population ${ }^{8}$ obtained from the INE, $E_{i, t}=n_{i, t} / P_{i, t}$. The average size of firms in the region is measured by the ratio between the regional labour force obtained from the INE and the stock of firms, $S_{i, t}=L_{i, t} / n_{i, t}$. Table 4 presents a summary of those variables.

Insert Table 4 about here

Regarding Equation [5], the independent variables are the aggregated value added for each region $\left(Y_{i, t-1}\right)$, the population density (number of inhabitants per square kilometre; $\left.D E N_{i, t-1}\right)$, the annual growth of the regional output $\left(g_{i, t-1}=\ln \left[Y_{i, t-1} / Y_{i, t-2}\right]\right)$, the tax pressure (ratio between taxes and GDP; $\left.T A X_{i, t-1}\right)$ and the regional unemployment $\left(U N E M_{i, t-1}\right)$. We have measured such determinants using information from the INE. In the estimations, these variables have been included one period lagged; therefore, we also collect regional data for 2003.

\section{Results}

Regarding Hypothesis 1, Table 5 shows different estimations of Equation [2] using the between and the within effects models, in this last case providing the clustered (by firm) robust variance estimators. Breush and Pagan's (1979) and Hausman's (1978) tests indicate that the fixed effects model is the most appropriate for modelling the non-observable heterogeneity among firms. The difference between the first and second pairs of columns is the inclusion of the variables measured at the regional level (in the best of cases, the increase in the explanatory power of the model, $\mathrm{R}^{2}$, is 0.0024). The last two columns show the joint estimation with Equation [5].

Insert Table 5 about here

\footnotetext{
${ }^{8}$ There is also information available about the economically active population. The estimations presented in the next section have been replicated using the ratio between the stock of the firms and the economically active population as the measure of entrepreneurship capital. The conclusions are very similar but, in this case, the models have a lower explanatory capacity, R square, than those of the estimations presented in the text.
} 
The elasticity of production with respect to labour $(\beta)$ takes values of between 0.7382 and 0.8914 , the elasticity with respect to capital $(\alpha)$ takes values of between 0.1680 and 0.2198 , and the elasticity of production with respect to private knowledge $(\rho)$ takes values of between 0.0051 and 0.0067. All of those parameters are statistically significant at the $1 \%$ level. The null hypothesis of the constant returns to scale is rejected in both models. In short, the elasticities of production with respect to the inputs purchased by the firms are very stable among the different models estimated.

This finding does not apply to the parameters associated with regional inputs (last four columns in Table 5). The coefficients associated with the regional entrepreneurship capital and knowledge are statistically significant only in the between effects model. Thus, Hypothesis 1 is only supported in the between effects model. The coefficients associated with the entrepreneurship capital are always positive and, in the between models, take the values 1.0313 and 1.0338, while in the within models, take the values 0.2362 and 0.4019 , which are 22 and 39 percent of those estimated in the between models ( $\theta$ between 0.22 and 0.39 ), respectively. The coefficients associated with regional knowledge are positive and statistically significant at the $10 \%$ level in the between effects model, while they are negative and statistically insignificant in the within effects model. The coefficients related to the average size of firms in the region are positive in all cases, but not statistically significant; therefore, we cannot reject that $s=0$. The average size of the firms in the region has no spillover on firms' productivity.

Regarding the determinants of the entrepreneurship capital (Equation [5]), we find evidence of their persistence and their positive correlation with the personal wealth of the inhabitants of the region, the regional output growth, the tax pressure and the unemployment ratio.

Regarding Hypothesis 2, Table 6 shows the estimations of the above models allowing for differences in the elasticities of production with respect to the entrepreneurship capital depending on the size and the technological intensity of the firm. Hypothesis 2 is supported in the within effects model and partially supported in the between effects model. The spillovers decrease with the size of the firm (statistically significant in both models) and increase with the technology intensity (only statistically significant in the within effects model). It is important to note that the elasticities of production with respect to the entrepreneurship capital for technological firms with less than 50 employees are very similar using the between effects model (approximately 1.46) and the within effects model (1.3057 and 1.4624; all of these values are statistically significant). This finding does not apply to the other types of firms. The values of the remaining parameters are consistent with the previous estimations in Table 5. 


\section{Conclusions}

Spatial externalities have been considered a main argument for justifying the existence of policies stimulating entrepreneurship among the population (Acs et al. 2016). This paper uses data at the firm level to test whether the regional entrepreneurship capital has positive spillovers on the production of the firms in the region. Previous evidence is based on aggregated data at the regional level. The theoretical discussion in this paper suggests that those studies may be overestimating the spillovers, particularly when the production functions present decreasing returns to scale, and the regional average size of the firms has no spillovers on the production of the firms of the region. Our evidence suggests that both features are present in the production functions estimated (at least in the within effects model); therefore, it is important to provide evidence at the firm level to confirm the presence of regional entrepreneurship capital spillovers. It is important to note that we do not provide evidence for the sources of the entrepreneurship capital spillovers (for such kind of evidence see Carree et al. 2014). Therefore, we cannot guarantee that the source of those spillovers is the KSTE argument, and we cannot reject the possibility of other sources of positive (or negative) spillovers being present at the same time.

For the overall sample of firms, we find that the regional entrepreneurship capital has positive spillovers on the production of the firms in the region; these are statistically significant in the between effects but not in the within effects model. Consequently, one could argue that we do not find clear support for such spillovers; however, those results could have different interpretations.

In accordance with Congregado et al. (2012), the ratio of the stock of firms and the population is a measure of the latent variable, entrepreneurship capital. The annual variation in the measure is an imperfect indicator of the annual variation in the latent variable. According to Congregado et al. (2012) and our estimations, approximately $20-35 \%$ of the variation in the measure is related to a variation in the latent variable.

Another interpretation is that we have omitted time invariant variables correlated with entrepreneurship capital. If this is the case, it appears that those variables are particularly relevant for non-technological firms. It is important to note that, for technological firms, the elasticities 
estimated are positive, statistically significant and with similar values in both models (between and within effects). We also find that, if there is a benefit, small firms benefit more from the regional entrepreneurship capital spillovers.

In short, we only detect generally extended positive spillovers in between effects models, while in the within effects models, significant positive spillovers are only found for technological firms. Our results need to be confirmed in other contexts: different geographical areas, different definitions of region and different periods of time. The evidence presented opens interesting theoretical and empirical questions among which are the omitted time invariant variables correlated with the regional entrepreneurship capital and the production of the firms in the region. 


\section{References}

Acs, Z., Braunerhjelm, P., Audretsch, D. \& Carlsson, B. (2009). The Knowledge Spillover Theory of Entrepreneurship. Small Business Economics, 32(1), 15-30. doi: 10.1007/s11187-008-9157-3.

Acs, Zoltan J., Åstebro, T., Audretsch, D. \&Robinson, D. (2016). Public policy to promote entrepreneurship: a call to arms. Small Business Economics, 47 (1):35-51. doi: 10.1007/s11187016-9712-2.

Audretsch, D., \& Keilbach, M. (2004a). Does entrepreneurship capital matter? Entrepreneurship Theory and Practice, 28(5), 419-429. doi: 10.1111/j.1540-6520.2004.00055.x.

Audretsch, D., \& Keilbach, M. (2004b). Entrepreneurship and Regional Growth: an Evolutionary Interpretation. Journal of Evolutionary Economics, 14(5), 605-616. doi: 10.1007/s00191-0040228-6.

Audretsch, D., \& Keilbach, M. (2004c). Entrepreneurship capital and economic performance. Regional Studies, 38(8), 949-959. doi: 10.1080/0034340042000280956.

Audretsch, D., \& Keilbach, M. (2005). Entrepreneurship capital and Regional Growth. Annals of Regional Science, 39(3), 457-469. doi: 10.1007/s00168-005-0246-9.

Audretsch, D., \& Keilbach, M. (2007). The Theory of Knowledge Spillover Entrepreneurship. Journal of Management Studies, 44(7), 1242-1254. doi: 10.1111/j.1467-6486.2007.00722.x.

Audretsch, D., \& Keilbach, M. (2008). Resolving the knowledge paradox: Knowledge-spillover Entrepreneurship and Economic Growth. Research Policy,37(10), 1697-1705. doi: 10.1016/j.respol.2008.08.008.

Audretsch, D., \& Lehmann, E. (2016). Economic performance and the knowledge spillover theory of entrepreneurship: a comment, The Journal of Technology Transfer (2016). doi: 10.1007/s10961016-9507-2.

Barge-Gil, A. \& López, A. (2013). R\&D and Productivity: In search of complementary between research and development activities, MPRA Paper 43808.

[https://mpra.ub.uni-muenchen.de/43808/1/MPRA_paper_43808.pdf]

Böente, W., Heblich, S. \& Jarosch, M. (2008). Entrepreneurship Capital, Knowledge Spillovers and Regional Productivity: Some Empirical Evidence from European Regions. Working Paper IAREG WP3/05.

[https://www.researchgate.net/profile/Werner_Boente/publication/237702949_Entrepreneurship _Capital_Knowledge_Spillovers_and_Regional_Productivity_Some_Empirical_Evidence_from _European_Regions/links/00b495268116228ce7000000.pdf]

Breusch, T., \& Pagan A. (1979). A Simple Test for Heteroscedasticity and Random Coefficient Variation. Econometrica, 47(5), 1287-1294. doi: 10.2307/1911963.

Chang, E.; Misra, K. \& Memili, E. (2012). Expanding the Notion of Entrepreneurship Capital in American Counties: A Panel Data Analysis 2002-2007. Journal of Developmental Entrepreneurship, 17(3), 1-18. doi: 10.1142/S108494671250015X.

Cobb, C. \& Douglas, P. (1928). A Theory of Production. American Economic Review, 18, 139-165. doi: $10.1155 / 2013 / 761832$.

Cohen, W. \& Levinthal, D. (1990). Absorptive capacity: a new perspective on innovation and learning. Administrative Sciences Quartery, 35, 128-152. doi: 10.2307/2393553.

Congregado, E., Golpe, A. \& Parker, S. (2012). The dynamics of entrepreneurship: hysteresiss, business cycles and government policy. Empirical Economics, 43(3), 1239-1261. doi:10.1007/s00181-0110516-6.

Cravo, T., Gourlay, A. \& Becker, B. (2010). SMEs and Regional Economic Growth in Brazil. Small Business Economics, 38, 217-230. doi: 10.1007/s11187-010-9261-z.

Carree, M., Della Malva, A. \& Santarelli, E. (2014). The contribution of universities to growth: empirical evidence for Italy. Journal of Technology Transfer, 39(3), 393-414. doi:10.1007/s10961-0129282-7.

Erikson, T. (2002). Entrepreneurial capital: the emerging venture's most important asset and competitive advantage. Journal of Business Venturing, 17, 275-290. doi:10.1016/S0883-9026(00)00062-8.

Erken, H., Donselaar, P. \& Thurik, R. (2016). Total factor productivity and the role of entrepreneurship, The Journal of Tehcnology Transfer. doi:10.1007/s10961-016-9504-5.

Fairlie, R. (2013). Entrepreneurship, Economic Conditions, and the Great Recession. Journal of Economics \& Management Strategy, 22: 207-231. doi:10.1111/jems.12017. 
Ferreira, P., Pessôa, S. \& Veloso, F. (2013), On the Evolution of Total Factor Productivity in Latin America, Economic Inquiry, 51: 16-30. doi:10.1111/j.1465-7295.2011.00430.x

Fisher, F. (1969). The existence of aggregate production functions, Econometrica, 37 (4), pp. 553-77. doi: $10.2307 / 1910434$.

Fisher, F. (2005). Aggregate Production Functions-A Pervasive, but Unpersuasive, Fairytale, Eastern Economic Journal, 31(3), 489-91. [http://college.holycross.edu/eej/Volume31/V31N3P489_491.pdf].

Fritsch, M. \& Wyrwich, M. (2014). The Long Persistence of Regional Levels of Entrepreneurship: Germany, 1925-2005, Regional Studies, 48(6), 955-973. doi: 10.1080/00343404.2013.816414.

Gentry, W. \& Hubbard, R. (2000). Tax policy and entrepreneurial entry. American Economic Review, 90(2), 283-287. doi: 10.1257/aer.90.2.283

Geroski, P. (1989). Entry, Innovation and Productivity Growth. The Review of Economics and Statistics 71(4), 572-78. doi: 10.2307/1928098.

Goya, E. \& Vayá, E. (2011). Productivity and Innovation Spillovers: Micro evidence from Spain, Research Institute of Applied Economics, Working Paper, 24, 1-38. [http://www.ub.edu/irea/working_papers/2011/201126.pdf]

Griliches, Z. (1998). The Search for R\&D Spillovers: The Econometric Evidence. National Bureau of Economic Research, 251-268. [http://www.nber.org/chapters/c8349].

Gutiérrez, O. and Ortín-Ángel, P. (2016). Entrepreneurship and the Legal Form of Businesses: The Role of Differences in Beliefs. Review of Law \& Economics. 12(1), 119-151. doi: 10.1515/rle-20140027.

Henrekson, M. \& Sanandaji, T. (2014). Small business activity does not measure entrepreneurship. Proceedings of the National Academy of Sciences of the United States of America, 111(5), 17601765. doi: 10.1073/pnas.1307204111

Hafer, R. (2013). Entrepreneurship and State Economic Growth. Journal of Entrepreneurship and Public Policy, 2, 67-79. doi: 10.1108/20452101311318684.

Hausman, J. (1978). Specification Tests in Econometrics. Econometrica, 46(6), 1251-1271. doi: $10.2307 / 1913827$.

Kirzner, I. (1979). Perception, Opportunity and Profit, Studies in the Theory of Entrepreneurship. University of Chicago Press, Chicago and London.

Knight, F. (1921) Risk Uncertainty and Profit. Houghton Mifflin, Boston and New York. [http://www.econlib.org/library/Knight/knRUP.html].

Koellinger, P. \& Thurik, R. (2012). Entrepreneurship and the Business Cycle, Review of Economics and Statistics 94(4), 1143-1156. doi:10.1162/REST_a_00224.

Laborda, L., Guasch J. \& Sotelsek, D. (2011). Entrepreneurship Capital and Technical Efficiency, The Role of New Business/Firms as a Conduit of Knowledge Spillovers. Entrepreneurship Research Journal 1(4). doi: 10.2202/2157-5665.1023.

Mendonça, J. \& Grimpe, C. (2015). Skills and regional entrepreneurship capital formation: a comparison between Germany and Portugal. Journal of Technology Transfer, 1-17. doi: 10.1007/s10961-0159444-5.

Mueller, P. (2006). Exploring the knowledge filter: How entrepreneurship and university-industry relationships drive economic growth. Research Policy, 35(10), 1499-1508. doi: 10.1016/j.respol.2006.09.023

Mueller, P. (2007). Exploiting Entrepreneurial Opportunities: The Impact of Entrepreneurship on Growth. Small Business Economics, 28(4), 355-362. doi: 10.1007/s11187-006-9035-9.

Ortega-Argilés, R.; Potters, L. \& Vivarelly, M. (2011). R\&D and Productivity: testing sectoral peculiarities using micro data. Empirical Economics, 41, 817-839. doi: 10.1007/s00181-010-0406-3.

Qian, H. \& Acs, Z. (2013). An absorptive capacity theory of knowledge spillover entrepreneurship, Small Business Economics (40)185, 185-197. doi:10.1007/s11187-011-9368-x.

Roberts, M., \& Tybout, J. (1996). Industrial Evolution in Developing Countries: Micro Patterns of Turnover, Productivity, and Market Structure. Oxford University Press, Oxford. [http://trove.nla.gov.au/version/18645868]

Salas-Fumás, V. \& Sanchez-Asin, J. (2013a). Entrepreneurial dynamics of the self-employed and of firms: a comparison of determinants using Spanish data. International Entrepreneurship and Management Journal, 9, 417-446. doi: 10.1007/s11365-011-0178-z.

Salas-Fumás, V. \& Sanchez-Asín, J. (2013b). The management function of entrepreneurs and countries' productivity growth. Applied Economics, 45, 2349-2360. doi: 10.1080/00036846.2012.663476.

Say, J. (1803). A Treatise on Political Economy. [http://www.econlib.org/library/Say/sayT.html]. 
Schumpeter, J. (1950). Capitalism, Socialism and Democracy. New York: Harper \& Row, 1942, Third edition. [http://cnqzu.com/library/Economics/marxian\%20economics/Schumpeter,\%20JoesephCapitalism,\%20Socialism\%20and\%20Democracy.pdf]

Solow, R. (1956). A Contribution to the Theory of Economic Growth. The Quarterly Journal of Economics, 70(1), 65-94. doi: 10.2307/1884513.

Stough, R., Jackson, S., Song Ch., \& Sutter, R. (2008). Measuring Entrepreneurship Capital and its Role in Economic Growth, in A. Bailly, L. Gibson and K. Haynes (Eds.). Applied Geography for the Entrepreneurial University, Economica, France, 137-150. [https://www.brookings.edu/book/applied-geography-for-the-entrepreneurial-university]

Sutter, R., \& Stough, R. (2009). Measuring Entrepreneurship and Knowledge Capital: Metropolitan Economic Efficiency in the USA? Entrepreneurship \& Regional Development, 21(4), 351-373. doi: $10.1080 / 08985620903020052$.

Syverson, C. (2011). What Determine Productivity? Journal of Economic Literature, 49(2), 326-365. doi: $10.3386 / \mathrm{w} 15712$.

Van den Steen, E. (2010). Interpersonal Authority iu a Theory of the Firm. American Economic Review, 100(1), 466-490. doi:10.1257/aer.100.1.466. 
Table 1. Descriptive variables.

\begin{tabular}{lrr}
\hline $\begin{array}{l}\text { Information on the firm } \\
\text { level }\end{array}$ & Mean & $\begin{array}{r}\text { Standard } \\
\text { Deviation }\end{array}$ \\
\hline & & 2.1288 \\
$\ln Y_{i, i, t}$ & 15.5697 & 2.4080 \\
$\ln K_{i, i, t}$ & 14.3528 & 1.7025 \\
$\ln L_{i, i, t}$ & 4.1255 & 5.3774 \\
$\ln Z_{i, i, t}$ & 6.082 &
\end{tabular}

Observations: 89,370

Number of Firms: 11,276

\section{Information on the region}

$\begin{array}{lrr}\ln Y_{i, t} & 17.0336 & 1.1507 \\ \ln R_{i, t} & 4.6072 & 1.2440 \\ \ln D E N_{i, t} & 4.8166 & 1.2580 \\ U N E M P_{i, t} & 0.4208 & 0.0405 \\ g_{Y, t} & 0.0104 & 0.0260 \\ T A X_{i, t} & 0.1009 & 0.0542\end{array}$

Observations: 162

Number of Regions: 18

Table 2. Categories of technological sectors: INE.

\begin{tabular}{llc}
\hline NACE & Sectors & Category=c \\
\hline 72 & Scientific research and development & \\
& $721 \quad$ Research and experimental development on natural sciences and engineering & \\
& $722 \quad$ Research and experimental development on social sciences and humanities & Very high tech \\
59 & Motion picture, video \& TV programme production, sound recording \& music publishing & [HT] \\
60 & Programming and broadcasting activities & High \& medium tech \\
61 & Telecommunications & [MT] \\
62 & Computer programming, consultancy and related activities & \\
63 & Information service activities & \\
\hline 21 & Manufacture of basic pharmaceutical products and pharmaceutical preparations \\
26 & Manufacture of computer, electronic and optical products & \\
& $303 \quad$ Manufacture of air and spacecraft and related machinery & \\
20 & Manufacture of chemicals and chemical products & \\
25 & Manufacture of fabricated metal products, except machinery and equipment & \\
29 & Manufacture of electrical equipment & Manufacture of motor vehicles, trailers and semi-trailers \\
30 & Manufacture of other transport equipment & \\
& $325 \quad$ Manufacture of medical and dental instruments and supplies
\end{tabular}

Source: http://www.ine.es/daco/daco43/notaiat.pdf 
Table 3. Distribution of firms by technological intensity and size categories.

\begin{tabular}{rrrrrr}
\hline \multirow{2}{*}{ Firm Size } & $\begin{array}{r}\text { Number of } \\
\text { Workers }\end{array}$ & Low Tech [LT] & Medium Tech [MT] & High Tech [HT] & Total \\
\hline & & & & & \\
Small & {$[1-49]$} & 3,606 & 184 & 1,046 & 4,836 \\
Medium & {$[50-249]$} & 2,431 & 160 & 837 & 3,428 \\
Large & {$[>=250]$} & 2,277 & 356 & 379 & 3,012 \\
Total & & 8,314 & 700 & 2,262 & 11,276
\end{tabular}

Table 4. Regional entrepreneurship capital.

\begin{tabular}{lcc} 
& & Means \\
\hline & $\ln \left(E_{i t}\right)$ & $\ln s_{i t}$ \\
\hline Andalusia & & 1.7819 \\
Aragon & -2.7950 & 1.8276 \\
Asturias & -2.6590 & 1.7660 \\
Balearic Is. & -2.7122 & 1.6784 \\
Canary Is. & -2.4707 & 1.8151 \\
Cantabria & -2.7215 & 1.8384 \\
Castilla La Mancha & -2.6964 & 1.7988 \\
Castilla y Leon & -2.7335 & 1.8042 \\
Catalonia & -2.7043 & 1.6891 \\
Ceuta & -2.4866 & 1.8967 \\
Extremadura & -2.9949 & 1.7853 \\
Galicia & -2.8085 & 1.7521 \\
La Rioja & -2.6335 & 1.7878 \\
Madrid & -2.6112 & 1.7637 \\
Murcia & -2.5267 & 1.8379 \\
Navarra & -2.7353 & 1.8777 \\
Basque Country & -2.6750 & 1.7570 \\
Valencia & -2.5635 & 1.7528 \\
Total & -2.6305 & 1.7542 \\
\end{tabular}


Table 5. Test of Hypothesis 1.

\begin{tabular}{|c|c|c|c|c|c|c|c|c|c|c|c|c|c|}
\hline \multirow[b]{2}{*}{ Model } & & \multicolumn{12}{|c|}{ Equation [4]: Dependent Variable: $\ln Y_{j, i, t}$} \\
\hline & & \multicolumn{2}{|l|}{ Between } & \multicolumn{2}{|l|}{ Within } & \multicolumn{2}{|l|}{ Between } & \multicolumn{2}{|l|}{ Within } & \multicolumn{2}{|l|}{ Between } & \multicolumn{2}{|l|}{ Within } \\
\hline $\begin{array}{l}\text { Independent } \\
\text { Variable }\end{array}$ & Coef. & & & & & & & & & & & & \\
\hline Constant & & $\begin{array}{r}8.8670 \\
{[0.088]}\end{array}$ & $* * *$ & $\begin{array}{r}10.0661 \\
{[0.219]}\end{array}$ & $* * *$ & $\begin{array}{r}10.7188 \\
{[0.461]}\end{array}$ & $* * *$ & $\begin{array}{r}10.6614 \\
{[0.490]}\end{array}$ & $* * *$ & $\begin{array}{r}10.7166 \\
{[0.461]}\end{array}$ & $* * *$ & $\begin{array}{r}11.0099 \\
{[0.549]}\end{array}$ & $* * *$ \\
\hline $\ln L_{j, i, t}$ & $\beta$ & $\begin{array}{c}0.8914 \\
{[0.007]}\end{array}$ & $* * *$ & $\begin{array}{r}0.7387 \\
{[0.016]}\end{array}$ & $* * *$ & $\begin{array}{r}0.8793 \\
{[0.007]}\end{array}$ & $* * *$ & $\begin{array}{c}0.7384 \\
{[0.016]}\end{array}$ & $* * *$ & $\begin{array}{r}0.8793 \\
{[0.007]}\end{array}$ & $* * *$ & $\begin{array}{c}0.7382 \\
{[0.016]}\end{array}$ & $* * *$ \\
\hline $\ln K_{j, i, t}$ & $\alpha$ & $\begin{array}{r}0.2148 \\
{[0.005]}\end{array}$ & $* * *$ & $\begin{array}{r}0.1684 \\
{[0.016]}\end{array}$ & $* * *$ & $\begin{array}{r}0.2198 \\
{[0.005]}\end{array}$ & $* * *$ & $\begin{array}{r}0.1682 \\
{[0.016]}\end{array}$ & $* * *$ & $\begin{array}{r}0.2198 \\
{[0.005]}\end{array}$ & $* * *$ & $\begin{array}{c}0.1680 \\
{[0.016]}\end{array}$ & $* * *$ \\
\hline $\ln Z_{j, i, t}$ & $\rho$ & $\begin{array}{r}0.0067 \\
{[0.002]}\end{array}$ & $* * *$ & $\begin{array}{r}0.0053 \\
{[0.001]}\end{array}$ & $* * *$ & $\begin{array}{r}0.0051 \\
{[0.002]}\end{array}$ & $* * *$ & $\begin{array}{r}0.0053 \\
{[0.001]}\end{array}$ & $* * *$ & $\begin{array}{r}0.0051 \\
{[0.002]}\end{array}$ & $* * *$ & $\begin{array}{r}0.0053 \\
{[0.001]}\end{array}$ & $* * *$ \\
\hline $\ln R_{i, t}$ & $\mu$ & & & & & $\begin{array}{r}0.0247 \\
{[0.013]}\end{array}$ & $*$ & $\begin{array}{r}-0.0173 \\
{[0.019]}\end{array}$ & & $\begin{array}{r}0.0248 \\
{[0.013]}\end{array}$ & $*$ & $\begin{array}{r}-0.0201 \\
{[0.019]}\end{array}$ & \\
\hline $\ln E_{i, t}$ & $\delta$ & & & & & $\begin{array}{r}1.0338 \\
{[0.132]}\end{array}$ & $* * *$ & $\begin{array}{r}0.2362 \\
{[0.197]}\end{array}$ & & $\begin{array}{r}1.0313 \\
{[0.132]}\end{array}$ & $* * *$ & $\begin{array}{r}0.4019 \\
{[0.227]}\end{array}$ & $*$ \\
\hline $\ln s_{i, t}$ & $\gamma$ & & & & & $\begin{array}{r}0.3752 \\
{[0.263]}\end{array}$ & & $\begin{array}{r}0.0693 \\
{[0.151]}\end{array}$ & & $\begin{array}{r}0.3726 \\
{[0.263]}\end{array}$ & & $\begin{array}{r}0.1275 \\
{[0.154]}\end{array}$ & \\
\hline Temporal Effec & & Yes & & Yes & & Yes & & Yes & & Yes & & Yes & \\
\hline$R^{2}$ & & 0.8170 & & 0.3241 & & 0.8194 & & 0.3241 & & 0.8194 & & 0.3241 & \\
\hline & & & & & & Equation [ & 5] De & Adent Vari & able: $\ln \mathrm{E}_{i, t}$ & & & & \\
\hline Constant & & & & & & & & & & $\begin{array}{r}-0.0699 \\
{[0.004]}\end{array}$ & $* * *$ & $\begin{array}{r}-8.8545 \\
{[0.133]}\end{array}$ & $* * *$ \\
\hline $\ln E_{i, t-1}$ & $\pi_{1}$ & & & & & & & & & $\begin{array}{c}0.9812 \\
{[0.001]}\end{array}$ & $* * *$ & $\begin{array}{r}0.3369 \\
{[0.004]}\end{array}$ & $* * *$ \\
\hline $\ln Y_{j, i, t-1}$ & $\pi_{2}$ & & & & & & & & & $\begin{array}{c}0.0049 \\
{[0.000]}\end{array}$ & $* * *$ & $\begin{array}{c}0.5518 \\
{[0.006]}\end{array}$ & $* * *$ \\
\hline$g_{Y i, t}$ & $\pi_{3}$ & & & & & & & & & $\begin{array}{c}0.7434 \\
{[0.016]}\end{array}$ & $* * *$ & $\begin{array}{r}0.3240 \\
{[0.007]}\end{array}$ & $* * *$ \\
\hline $\ln D E N_{i, t-1}$ & $\pi_{4}$ & & & & & & & & & $\begin{array}{r}-0.0021 \\
{[0.000]}\end{array}$ & $* * *$ & $\begin{array}{r}-0.3869 \\
{[0.004]}\end{array}$ & $* * *$ \\
\hline$T A X_{i, t-I}$ & $\pi_{5}$ & & & & & & & & & $\begin{array}{c}0.0631 \\
{[0.002]}\end{array}$ & $* * *$ & $\begin{array}{r}0.1150 \\
{[0.004]}\end{array}$ & $* * *$ \\
\hline$U N E M P_{i, t-1}$ & $\pi_{6}$ & & & & & & & & & $\begin{array}{c}0.0648 \\
{[0.002]}\end{array}$ & $* * *$ & $\begin{array}{r}0.0519 \\
{[0.007]}\end{array}$ & $* * *$ \\
\hline $\begin{array}{l}\text { Observations } \\
\text { Groups }\end{array}$ & $\begin{array}{l}89,370 \\
11,276\end{array}$ & & & & & & & & & & & & \\
\hline
\end{tabular}

*: Significant at the 0.10 level. **: Significant at the 0.05 level. ***: Significant at the 0.01 level. Robust standard errors are in brackets. 
Table 6. Test of Hypothesis 2.

\begin{tabular}{|c|c|c|c|c|c|c|c|c|c|}
\hline \multirow[b]{2}{*}{ Model } & & \multicolumn{8}{|c|}{ Equation [4] Dependent Variable: $\ln Y_{j, i, t \cdot}$} \\
\hline & & \multicolumn{2}{|l|}{ Between } & \multicolumn{2}{|l|}{ Within } & \multicolumn{2}{|l|}{ Between } & \multicolumn{2}{|l|}{ Within } \\
\hline $\begin{array}{l}\text { Independent } \\
\text { Variable }\end{array}$ & Coefficient & & & & & & & & \\
\hline Constant & & $\begin{array}{r}11.3732 \\
{[0.532]}\end{array}$ & $* * *$ & $\begin{array}{r}10.6246 \\
{[0.488]}\end{array}$ & $* * *$ & $\begin{array}{r}11.3580 \\
{[0.532]}\end{array}$ & $* * *$ & $\begin{array}{r}11.0201 \\
{[0.546]}\end{array}$ & $* * *$ \\
\hline $\ln L_{j, i, t}$ & $\beta$ & $\begin{array}{r}0.8358 \\
{[0.009]}\end{array}$ & $* * *$ & $\begin{array}{r}0.7379 \\
{[0.016]}\end{array}$ & $* * *$ & $\begin{array}{r}0.8358 \\
{[0.009]}\end{array}$ & $* * *$ & $\begin{array}{r}0.7377 \\
{[0.016]}\end{array}$ & $* * *$ \\
\hline $\ln K_{j, i, t}$ & $\alpha$ & $\begin{array}{r}0.2156 \\
{[0.005]}\end{array}$ & $* * *$ & $\begin{array}{r}0.1643 \\
{[0.016]}\end{array}$ & $* * *$ & $\begin{array}{r}0.2155 \\
{[0.005]}\end{array}$ & $* * *$ & $\begin{array}{r}0.1638 \\
{[0.016]}\end{array}$ & $* * *$ \\
\hline $\ln Z_{j, i, t}$ & $\rho$ & $\begin{array}{r}0.0024 \\
{[0.002]}\end{array}$ & & $\begin{array}{r}0.0052 \\
{[0.001]}\end{array}$ & $* * *$ & $\begin{array}{r}0.0024 \\
{[0.002]}\end{array}$ & & $\begin{array}{r}0.0052 \\
{[0.001]}\end{array}$ & $* * *$ \\
\hline $\ln R_{i, t}$ & $\mu$ & $\begin{array}{r}0.0243 \\
{[0.013]}\end{array}$ & $*$ & $\begin{array}{r}-0.0162 \\
{[0.019]}\end{array}$ & & $\begin{array}{r}0.0245 \\
{[0.013]}\end{array}$ & $*$ & $\begin{array}{r}-0.0196 \\
{[0.019]}\end{array}$ & \\
\hline $\ln s_{i, t}$ & $\gamma$ & $\begin{array}{r}0.5297 \\
{[0.259]}\end{array}$ & $* *$ & $\begin{array}{r}0.0852 \\
{[0.150]}\end{array}$ & & $\begin{array}{r}0.5235 \\
{[0.259]}\end{array}$ & $* *$ & $\begin{array}{r}0.1540 \\
{[0.154]}\end{array}$ & \\
\hline $\ln E_{i, t}$ & $\delta$ & $\begin{array}{r}1.3861 \\
{[0.172]}\end{array}$ & $* * *$ & $\begin{array}{r}0.3706 \\
{[0.226]}\end{array}$ & & $\begin{array}{r}1.3764 \\
{[0.172]}\end{array}$ & $* * *$ & $\begin{array}{r}0.6115 \\
{[0.264]}\end{array}$ & $* *$ \\
\hline $\mathrm{Big}_{j, i, t}$ & $\alpha_{B i g}$ & $\begin{array}{r}-1.0298 \\
{[0.442]}\end{array}$ & $* *$ & & & $\begin{array}{r}-1.0150 \\
{[0.442]}\end{array}$ & $* *$ & & \\
\hline $\operatorname{Tech}_{j, i, t}$ & $\alpha_{T e c h}$ & $\begin{array}{r}0.5652 \\
{[0.493]}\end{array}$ & & & & $\begin{array}{r}0.5726 \\
{[0.493]}\end{array}$ & & & \\
\hline $\ln E_{i, t} * B i g_{j, i, t}$ & $\delta_{B i g}$ & $\begin{array}{r}-0.4747 \\
{[0.170]}\end{array}$ & $* * *$ & $\begin{array}{r}-0.6957 \\
{[0.142]}\end{array}$ & $* * *$ & $\begin{array}{r}-0.4690 \\
{[0.170]}\end{array}$ & $* * *$ & $\begin{array}{r}-0.7679 \\
{[0.145]}\end{array}$ & $* * *$ \\
\hline $\ln \mathrm{E}_{i, t} * \operatorname{Tech}_{j, i, t}$ & $\delta_{\text {Tech }}$ & $\begin{array}{r}0.0831 \\
{[0.190]}\end{array}$ & & $\begin{array}{c}0.9351 \\
{[0.148]}\end{array}$ & $* * *$ & $\begin{array}{r}0.0860 \\
{[0.190]}\end{array}$ & & $\begin{array}{r}0.8919 \\
{[0.149]}\end{array}$ & $* * *$ \\
\hline Temporal Effects & & Yes & & Yes & & Yes & & Yes & \\
\hline$R^{2}$ & & 0.8258 & & 0.3251 & & 0.8258 & & 0.3251 & \\
\hline & & & & Equatior & {$[5] \mathrm{D}$} & ariable: $\ln$ & $E_{i, t}$ & & \\
\hline Constant & & & & & & $\begin{array}{r}-0.0751 \\
{[0.004]}\end{array}$ & $* * *$ & $\begin{array}{r}-8.3585 \\
{[0.132]}\end{array}$ & $* * *$ \\
\hline $\ln E_{i, t-1}$ & $\pi_{3}$ & & & & & $\begin{array}{r}0.9787 \\
{[0.001]}\end{array}$ & $* * *$ & $\begin{array}{r}0.3158 \\
{[0.004]}\end{array}$ & $* * *$ \\
\hline $\ln Y_{j, i, t-1}$ & $\pi_{1}$ & & & & & $\begin{array}{r}0.0048 \\
{[0.000]}\end{array}$ & $* * *$ & $\begin{array}{r}0.5206 \\
{[0.006]}\end{array}$ & $* * *$ \\
\hline$g_{Y i, t}$ & $\pi_{2}$ & & & & & $\begin{array}{r}0.7383 \\
{[0.016]}\end{array}$ & $* * *$ & $\begin{array}{r}0.3105 \\
{[0.007]}\end{array}$ & $* * *$ \\
\hline $\ln D E N_{i, t-1}$ & $\pi_{4}$ & & & & & $\begin{array}{r}-0.0021 \\
{[0.000]}\end{array}$ & $* * *$ & $\begin{array}{r}-0.3621 \\
{[0.003]}\end{array}$ & $* * *$ \\
\hline$T A X_{i, t-1}$ & $\pi_{6}$ & & & & & $\begin{array}{r}0.0633 \\
{[0.002]}\end{array}$ & $* * *$ & $\begin{array}{r}0.1063 \\
{[0.003]}\end{array}$ & $* * *$ \\
\hline$U N E M P_{i, t-1}$ & $\pi_{5}$ & & & & & $\begin{array}{r}0.0647 \\
{[0.002]}\end{array}$ & $* * *$ & $\begin{array}{r}0.0506 \\
{[0.007]}\end{array}$ & **** \\
\hline $\begin{array}{l}\text { Observations } \\
\text { Groups }\end{array}$ & $\begin{array}{l}89,370 \\
11,276\end{array}$ & & & & & & & & \\
\hline
\end{tabular}

*: Significant at the 0.10 level. **: Significant at the 0.05 level. ***: Significant at the 0.01 level. Robust standard errors are in brackets. 


\section{Appendix 1. Firm location.}

The firms are allocated to Autonomous Communities (Comunidades Autónomas - CCAAs) on the basis of where they perform their research activities. Specifically, for each firm, there is information available to calculate the percentage of the following expenditures: Total Expenditure on Innovation, Total Internal Personnel in R\&D Activities and Total Internal Expenditure on R\&D located in each of the 18 CCAA's. 8,012 firms make $100 \%$ of each of the expenditures in the same Autonomous Community. The first column (Location of R\&D Activities) in Table A.1. shows their distribution among CCAAs.

The remaining 4,826 firms were allocated to a CCAA if:

i) The same Autonomous Community concentrates $100 \%$ of the expenditure on which we have information ( 1 or 2 types of expenditure).

ii) This Autonomous Community is the one with the highest expenditure level at least in two of the three types of expenditures considered.

After this process, 1,020 firms cannot be allocated to a specific CCAA. The second column (Location of most R\&D Activities) in Table A.1 shows the distribution of the firms finally allocated after this process.

The PITEC database also contains information about where the headquarters of the firm are located. The problem is that they only recognize three Autonomous Communities: Madrid, Catalonia and Andalusia. To those Autonomous Communities, 4,848 firms are allocated, while 5,719 firms are allocated to the other CCAAs without identifying which. Furthermore, there are 1,465 missing values. The third column in Table A.1 summarizes the distribution of firms according to information about their headquarters. We use this information to check the robustness of the classification based on where the firms perform their research activities. We only find 590 divergences; therefore, we do not include such firms in the analyses. The last column (final firm location) in Table A.1 summarizes the distribution of firms among CCAA in the sample finally used in this paper. 
Table A.1. Sample and firms' regional distribution.

\begin{tabular}{|c|c|c|c|c|}
\hline REGION & $\begin{array}{r}A L L \\
R \& D \text { ACTIVITIES } \\
\text { LOCATION }\end{array}$ & $\begin{array}{r}\text { MOST of } \\
R \& D \text { ACTIVITIES } \\
\text { LOCATION }\end{array}$ & $\begin{array}{r}\text { HEADQUARTER } \\
\text { LOCATION }\end{array}$ & $\begin{array}{r}\text { FINAL } \\
\text { FIRM } \\
\text { LOCATION } \\
\end{array}$ \\
\hline Andalusia & 509 & 883 & 761 & 818 \\
\hline Aragon & 287 & 356 & & 348 \\
\hline Asturias & 158 & 197 & & 191 \\
\hline Balearic, Is. & 55 & 88 & & 87 \\
\hline Canary Is. & 66 & 125 & & 121 \\
\hline Cantabria & 93 & 123 & & 119 \\
\hline Castilla La Mancha & 130 & 201 & & 183 \\
\hline Castilla y Leon & 314 & 422 & & 404 \\
\hline Catalonia & 2,139 & 3,045 & 2,726 & 2,884 \\
\hline Ceuta & 1 & 3 & & 3 \\
\hline Extremadura & 68 & 87 & & 79 \\
\hline Galicia & 426 & 547 & & 537 \\
\hline La Rioja & 89 & 123 & & 118 \\
\hline Madrid & 1,108 & 2,384 & 2,167 & 2,241 \\
\hline Murcia & 201 & 264 & & 256 \\
\hline Navarra & 328 & 415 & & 406 \\
\hline Basque Country & 1,077 & 1,322 & & 1,263 \\
\hline Valencia & 963 & 1,244 & & 1,218 \\
\hline Firms localized & 8,012 & 11,818 & 4,848 & 11,276 \\
\hline Firms not localized & 4,826 & 1,020 & 7,184 & 1,562 \\
\hline PITEC Number of Firms & 12,838 & 12,838 & 12,838 & 12,838 \\
\hline
\end{tabular}

\section{Appendix 2. Firms' stock of capital.}

The PITEC provides information about the annual investment on the physical capital of each firm, $I_{j, t}$. In accordance with (Goya and Vayá 2011; Barge-Gil and López 2013, Ortega-Argilés et al. 2011), we use the perpetual inventory method to estimate the stock of capital of firm $j$ in period $t$ :

$$
K_{j, t}=(1-d) K_{j, t-1}+I_{j, t} \text { being } K_{j, 0}=I_{j, 0} / d .
$$

The depreciation rate adopted was $d=0.1$. Given that the investments are highly affected by economic fluctuations, in accordance with Ferreira et al. (2013), we use the average of all of the sample years' investments instead of $I_{j, 0}$. The basic results of this paper are insensitive to this decision. 